Article

\title{
The Function of HumAnimAllegory
}

\author{
Sean Meighoo
}

Department of Comparative Literature, Emory University, S410 Callaway Center, 537 Kilgo Circle, Atlanta, GA 30322, USA; sean.meighoo@emory.edu

Academic Editor: Joela Jacobs

Received: 27 July 2016; Accepted: 16 January 2017; Published: 22 January 2017

\begin{abstract}
This article presents a critical reading of the function of the animal-human allegory or the "humanimallegory" in both the animated films Animal Farm and Chicken Run. Based on George Orwell's novel of the same name, Animal Farm provides an allegorical representation of the Russian Revolution and the rise of Stalinism in the Soviet Union by relaying Orwell's story of a revolution led by a group of farm animals and its aftermath. Animal Farm ultimately reduces its fictional animal characters to simple metaphors for real human subjects, thus serving the most common function of the animal-human allegory in literature as well as film. In contrast, improvising on the many prisoner-of-war films that were produced during the first few decades following World War II, Chicken Run tells the story of a group of chickens who attempt to escape from an egg farm. Chicken Run complicates the function of the animal-human allegory, though, by resisting the allegorical reduction of its fictional animal characters to simple metaphors for real human subjects. By presenting a critical reading of these two different films, this article suggests that the literary concept of allegory itself remains circumscribed within the philosophical tradition of humanism.
\end{abstract}

Keywords: allegory; humanism; literary theory; film studies; animal studies; George Orwell; Animal Farm; Chicken Run

The neologism that I have coined for the title of this paper is what we might call a second-order neologism-a neologism that is composed of other neologisms-the word "humanimallegory" formed by crossing the words "humanimal" and "animallegory" with each other, neither of which word I can claim to have coined myself. The word "humanimal" was coined in the film You Never Can Tell, directed and co-written by Lou Breslow and released in 1951 [1]. ${ }^{1}$ This word has become quite ubiquitous within popular culture as well as the academic field of animal studies itself over the past few decades, largely aided, I would venture to guess, by its use in the theatrical trailer for the film The Island of Dr. Moreau, directed by Don Taylor and released in 1977 [2]. ${ }^{2}$ The word "animallegory" seems to have remained

1 You Never Can Tell is a comedy about a pet German Shepherd named King who inherits a fortune of six million dollars from his deceased owner, Andrew Lindsay. When King is poisoned under mysterious circumstances, the primary suspect is Lindsay's former secretary and the trustee of King's estate, Ellen Hathaway, who stands to inherit King's fortune. The word "humanimal" is introduced in an odd scene that is set apart from the rest of the film by its narrative voice-over, its musical score featuring electronic instrumentation, and its various special film effects including negative-image cinematography. During this scene, it is explained that all animals who have died must pass through "Beastatory" before they finally ascend into "the happy fields of Fauna." Any animal who has sinned and thus "betrayed the name of 'animal" is condemned to return to earth in a form "not animal, not human, but humanimal." Having entered Beastatory himself, King makes the unusual request to return to earth voluntarily in order to reveal the true identity of his killer. The rest of the film unfolds as King returns to earth as a private investigator, Rex Shepard, accompanied by a former racehorse named Golden Harvest who becomes his secretary, "Goldie." Both Shepard and Goldie appear to be human, but they retain many of their animal qualities like Shepard's taste for dog kibble and Goldie's ability to run at great speeds. Toward the end of the film, we discover that many of the characters who had seemed human were actually humanimal all along, although they do not realize it themselves. The implication, of course, is that any one of us film viewers might be humanimal as well.

2 The Island of Dr. Moreau was the second film adaptation of H. G. Wells's novel of the same name originally published in 1896 [3], the first film adaptation having been Island of Lost Souls, directed by Erle C. Kenton and released in 1932 [4]. 
much less widespread, though, despite its equally surprising long history. This word was coined in the 17 January 1955 edition of the weekly news magazine Time in a review of Halas and Batchelor's recently released animated film, Animal Farm [5]. Based on George Orwell's novel of the same name, Animal Farm provides an allegorical representation of the Russian Revolution and the subsequent rise of Stalinism in the Soviet Union by relaying Orwell's story of a revolution led by a group of farm animals and its aftermath [6]. Besides offering an expedient piece of political propaganda for the capitalist interests of the Western Bloc, Animal Farm ultimately reduces its fictional animal characters to simple metaphors for real human subjects, serving the most common function of the animal-human allegory in both literature and film - what I am calling here the function of humanimallegory.

Almost fifty years after the release of Animal Farm, Aardman's stop-motion animated film Chicken Run was released, marking yet another appearance of the humanimallegory. Improvising on the many prisoner-of-war films that were produced during the first few decades following World War II, Chicken Run tells the story of a group of chickens who attempt to escape from an egg farm [7]. I would like to argue that Chicken Run complicates the function of humanimallegory, however, by resisting the allegorical reduction of its fictional animal characters to simple metaphors for real human subjects. While Chicken Run certainly does play on many anthropomorphic representations of nonhuman animals, the film nonetheless also calls attention to the irreducible heterogeneity among its various animal characters-hens, roosters, rats, and dogs, not to mention human husband and wife-in some significant ways that Animal Farm does not. Reading these two different films in my paper, then, I want to suggest that the literary concept of allegory itself remains circumscribed within the philosophical tradition of humanism - which is to say, in so many words, that the theoretical distinction between the referent and the symbol that grounds the concept of allegory is a reiteration of the fundamentally metaphysical distinction between the human and the animal that grounds the tradition of humanism. ${ }^{3}$

It is fair to say that the concept of allegory has permeated the modern field of literary theory so completely that it is difficult if not impossible to cite any standard definition of this term. For our purposes, though, we may cite a working definition from Angus Fletcher's classic treatise Allegory: The Theory of a Symbolic Mode, which has remained widely available since its original publication in 1964. In his introduction to the text, Fletcher offers us a definition of allegory by contrasting it against the "open and direct" speech of "normal" language: "In the simplest terms, allegory says one thing and means another. It destroys the normal expectation we have about language, that our words 'mean what they say'. When we predicate quality $x$ of person $Y, Y$ really is what our predication says he [sic] is (or we assume so); but allegory would turn $\mathrm{Y}$ into something other (allos) than what the open and direct statement tells the reader" ([11], p. 2). In a note to this passage, Fletcher further provides us with an etymological derivation of the term itself: "Allegory from allos + agoreuein (other + speak openly, speak in the assembly or market). Agoreuein connotes public, open, declarative speech. This sense is inverted by the prefix allos" ([11], p. 2, n. 1). Following this definition, we could say that allegory introduces a discordance between "meaning" and "saying" that is not present in ordinary speech or language.

The word "humanimals" is used in the theatrical trailer for The Island of Dr. Moreau to describe the genetically mutated animals on whom Dr. Moreau secretly conducts his scientific experiments.

3 For some substantial scholarly works on film in the field of animal studies, see Akira Mizuta Lippit, Electric Animal: Toward a Rhetoric of Wildlife [8]; Jonathan Burt, Animals in Film [9]; and Paul Wells, The Animated Bestiary: Animals, Cartoons, and Culture [10]. Lippit, Burt, and Wells all make a claim on the special status of the animal in relation to the specific cultural forms in which they are interested-modern media, film, and animated films, respectively: in Electric Animal, Lippit argues that "[m]odernity can be defined by the disappearance of wildlife from humanity's habitat and by the reappearance of the same in humanity's reflections on itself: in philosophy, psychoanalysis, and technological media such as the telephone, film, and radio" ([8], pp. 2-3); in Animals in Film, Burt asserts that "[t]here is no doubt that the animal is a key figure in the history of filmmaking though, curiously, it is a fact that has been virtually ignored until recently" ([9], p. 196); and in The Animated Bestiary, Wells suggests that "[a]rguably, the animal is an essential component of the language of animation, but one so naturalized that the anthropomorphic agency of creatures from Winsor McCay's Gertie the Dinosaur to PIXAR's Nemo has not been particularly interrogated" ([10], p. 2). In The Animated Bestiary, Wells also discusses both the animated films Animal Farm and Chicken Run at some length ([10], pp. 54-59, 164-65). However, neither Lippit, Burt, nor Wells critically addresses the function of the animal-human allegory in literature or film as such. 
But if we were to question the humanist presuppositions that are entailed by this definition of allegory instead, then we would have to say that this discordance marks ordinary speech or language as well-breaching from the very start, as it were, any original accordance between meaning and saying, between the subject and the predicate, between the person and his or her personal quality or qualities. The function of humanimallegory is thus to restore order to the literary or filmic representation of the human by the animal as much as it is to restore order to the representation of the referent by the symbol. Yet insofar as this order has never been established or installed within language, literature, or film, this function is bound to fail—or, perhaps, to work only far too well.

Animal Farm was directed and produced by John Halas and Joy Batchelor for Louis de Rochemont and released in 1954, becoming the first British animated feature-length film to receive a public theatrical release. Halas was a Hungarian-born animator and Batchelor a British-born animator who formed the Halas and Batchelor animation studio together in 1940, marrying each other the same year. De Rochemont was an American filmmaker who was best known for his work as the co-producer and co-writer of the newsreel series The March of Time from 1935 to 1943. The film Animal Farm was "based on George Orwell's memorable fable," as the opening credits put it [6], and its story development credited to Lothar Wolff, Borden Mace, and Philip Stapp as well as Halas and Batchelor themselves. De Rochemont was also instrumental to the film's story development, however, apparently forcing Halas and Batchelor to change the rather bleak ending of Orwell's novel for the film adaptation. Produced during the first decade of the Cold War, Animal Farm obviously served the ideological agenda of anti-communism quite well. Yet it would not become public knowledge until half a century later that it was the United States Central Intelligence Agency (CIA) who had orchestrated de Rochemont's procurement of the film rights to Orwell's novel from his widow Sonia in 1951. Although it is not at all certain whether Halas and Batchelor were aware of the CIA's involvement in the film, it is not very surprising that they were hired to direct it given that they had produced animated propaganda films for the British war effort during World War II in addition to their short commercial films. On its release, Animal Farm was met with both critical and commercial success, spawning a serialized newspaper comic strip and even a line of merchandise.

The film opens on Manor Farm, which is owned and operated by the alcoholic and abusive farmer Mr. Jones. Late one night after Mr. Jones has returned from the local pub in a drunken stupor, the prize boar hog Old Major calls a meeting of all the farm animals in the main barn where he delivers a rousing speech, calling attention to humans' egregious exploitation of farm animals and culminating in the dictum, "All animals are equal." Old Major leads the farm animals in a stirring song before he suddenly keels over and dies. The next morning, the farm animals band together in revolt and forcibly drive Mr. Jones from the farm. When Mr. Jones returns with more men from the pub armed with various tools and weapons, the farm animals successfully repel the men's attack under the courageous leadership of the white pig Snowball. Over the next few days, the animals take control over the operation of the farm, destroying Mr. Jones's tools of coercion and slaughter and declaring his house forbidden to all. Under the continued leadership of Snowball, the animals change the name of Manor Farm to Animal Farm, and Snowball himself writes the laws of Animal Farm on the side of the barn for all to see: "No animal shall sleep in a bed-No animal shall drink alcohol—Four legs good two legs bad-No animal shall kill another animal-All animals are equal" [6]. Meanwhile, the dark-mottled pig Napoleon has secretly adopted the puppies who were orphaned during the men's attack on the farm, raising them for his own purposes. Some months later, when Snowball presents his plans for the construction of a windmill to the rest of the farm animals at one of their regular meetings in the barn, Napoleon summons the now full-grown dogs to chase Snowball from the farm and dispose of him. Napoleon assumes leadership of the farm with the support of his obedient follower Fat Pig Squealer, branding Snowball a traitor and discontinuing the farm animals' meetings. 
As the rest of the farm animals begin working on the construction of the windmill, the pigs begin sleeping in Mr. Jones's house and drinking alcohol which they obtain from the trader Mr. Whymper. When Squealer asks the hens to surrender all their eggs for the continuation of trade with the outside world, the hens stage a protest for which they are sentenced to death by Napoleon. Disgruntled by Mr. Whymper's commerce with the animals, the men from the pub decide to attack the farm again but this time without Mr. Jones. Although the farm animals successfully repel the attack under the leadership of Napoleon, they suffer a great setback when Mr. Jones manages to demolish the windmill with explosives. The farm animals begin working on the construction of the windmill again when the largest and strongest horse Boxer, who was wounded during the men's second attack on the farm, is permanently injured in the course of his selfless efforts to rebuild the windmill. While the rest of the farm animals expect that Boxer will be rewarded for his labors with a comfortable retirement, Napoleon and Squealer arrange to have him taken away in what first appears to be an ambulance but what turns out to be a truck in the service of Mr. Whymper's glue factory. Years later, after the construction of the windmill has been completed, Napoleon hosts a delegation of pigs from all the surrounding farms to which the Animal Revolution has spread. Now wearing suits and walking on their hind legs, the pigs have come to resemble Mr. Jones himself. Under Napoleon's dictatorship, Old Major's song has been forbidden, and the laws of Animal Farm have been rewritten. The farm animals are dismayed to discover that even Old Major's dictum has been altered: "All animals are equal but some animals are more equal than others" [6]. In a conclusion to the film that departs entirely from Orwell's novel, the rest of the surrounding farm animals finally converge on Animal Farm to overthrow Napoleon and all his fellow pigs in what is presumably the last revolution to be won.

But if we follow the allegorical reading of Animal Farm that the filmmakers seem to have intended for us, following Orwell himself-the allegorical reading of Animal Farm, moreover, that has totally dominated the critical analysis of both the novel and the film to date ${ }^{4}$-the story is not about any "animal revolution" at all. Rather, each and every character or event in Animal Farm only represents some particular human character or event in historical reality: Manor Farm represents Imperial Russia; Mr. Jones represents Tsar Nicholas II; Old Major represents Karl Marx; Old Major's song represents "The Internationale," also known as the International Workers' Hymn; the farm animals' revolt represents the Russian Revolution; Snowball represents both Vladimir Lenin and Leon Trotsky; the renaming of Animal Farm represents the creation of the Soviet Union; the laws of Animal Farm represent Lenin's April Theses; Napoleon represents Joseph Stalin; the windmill represents Trotsky's theory of permanent revolution; the dogs represent the Soviet secret police; Squealer represents Vyacheslav Molotov and the Soviet propaganda machine; Mr. Whymper represents unscrupulous capitalists; the execution of the hens represents Stalin's Great Purge; the men's second attack on the farm represents Nazi Germany's invasion of the Soviet Union during World War II; and the sale of Boxer to the glue factory represents the Soviet Union's betrayal of the workers. Now, I certainly do not want to deny that this allegorical reading of Animal Farm offers us a very interesting interpretation of the story. What I do want to point out, however, is that this reading is tightly regulated by the function of humanimallegory inasmuch as all the animals act as symbols for human referents. Although there are human characters in Animal Farm who also act as symbols, all the referents remain human. The animal as such never exceeds its purely symbolic function. Indeed, within the strict economy of the humanimallegory, the animal is a symbol and the human the transcendental referent. The distinction between the human and the animal thus reiterates the distinction made in linguistics and literary

4 Both Orwell's novels Animal Farm and 1984 have long become standard references in the scholarly body of work on allegory; in Allegory: The Theory of a Symbolic Mode, Fletcher mentions both novels during his discussion on what he considers the basic allegorical form of battle ([11], pp. 157-59). Similarly, Halas and Batchelor's film Animal Farm has been unanimously viewed as an adaptation of Orwell's original allegory, however faithful or not this adaptation is judged; in Time magazine's review of the film, it is affirmed that "[t]he story holds pretty true to Orwell...and the audience is asked to look the Soviet horror square in the eye" ([5], p. 74). 
theory alike between the signified and the signifier, between substance and form, between inner thought and outward expression. All of this is to say that metaphor is a metaphysics ${ }^{5}$-or, if you prefer, allegory is a humanism.

Chicken Run was directed by Peter Lord and Nick Park and produced by Lord, David Sproxton, and Park for DreamWorks Pictures in association with Pathé. Released in 2000, Chicken Run was Aardman's first feature-length film. The British animators Lord and Sproxton were longtime friends who formed the Aardman animation studio together in 1972. Their fellow British animator Park joined Aardman in 1985 while he was still working on his short film A Grand Day Out, the first film featuring the characters Wallace and Gromit on which he had begun working as a student at the National Film and Television School. Before the release of Chicken Run, Aardman produced many award-winning short films including Creature Comforts directed by Park as well as The Wrong Trousers and A Close Shave, two more films featuring Wallace and Gromit and also directed by Park, in addition to their commercial work and their assorted contributions to various television series and music videos. Chicken Run was "based on an original story" by Lord and Park, as the opening credits indicate [7], and its screenplay written by the American screenwriter Karey Kirkpatrick. Much like Park's short films, Chicken Run is marked not only by its dry and typically British sense of humor and its continuous stream of puns and sight gags but also by its distinctively animated and richly entertaining characters who usually cross the line between the human and the animal in some way. After the critical and commercial success of Chicken Run, Aardman went on to produce many more short films as well as feature-length films, including their first feature-length film featuring Wallace and Gromit The Curse of the Were-Rabbit and their first computer-animated film Flushed Away.

Chicken Run opens on Tweedy's Farm, an egg farm in the English countryside that has been owned and operated by the Tweedy family for generations. In the dark of night, amid high barbed-wire fencing and a roving searchlight, Mr. Tweedy patrols the farm with his two guard dogs as a small group of hens attempt to escape, led by Ginger who digs a trench under one of the fences with a spoon. The other hens fail to make it under the fence, however, and Ginger is cornered by the guard dogs at the farmhouse door when Mrs. Tweedy appears in the doorway, ordering Mr. Tweedy to put the hen back behind the fence. Mr. Tweedy throws Ginger into solitary confinement inside a yard bin before turning to the rest of the hens behind the fence and loudly declaring, "No chicken escapes from Tweedy's Farm!" [7]. The opening credits then roll over a series of other failed escape attempts by the hens, each one of which ends with Mr. Tweedy throwing Ginger into solitary confinement again. The story resumes as Mrs. Tweedy begins her weekly inspection of the chickens one morning. Ginger lines up with the rest of the hens, including Bunty, Babs, and Mac, as well as the old rooster and former Royal Air Force (RAF) officer Fowler. During the inspection, one of the hens who has failed to produce any eggs for the week, Edwina, is removed from the line-up and slaughtered by Mrs. Tweedy herself. That night, after Ginger and Mac present yet another escape plan at one of the chickens' secret meetings held in the sheds, Ginger witnesses a rooster flying through the air in a cape. He makes a crash landing onto the farm and injures one of his wings, while a torn poster reading "Rocky the Flying Rooster" floats down from the air into Ginger's hand-like wings. After he is brought into the chicken sheds, the rooster introduces himself to the other chickens as Rocky the Rhode Island Red, or "Rocky Rhodes" for short, further boasting that he is a freedom-loving chicken who they call the "Lone Free Ranger" back home in America. When Ginger learns that Rocky has escaped from the circus, she forces him to make a deal with her, promising to hide him only if he teaches all the chickens on the farm how to fly. Meanwhile, Mrs. Tweedy discovers a plan to make the farm more profitable.

5 On the relation of the literary concepts of metaphor, allegory, and symbol to the philosophical tradition of metaphysics, see Jacques Derrida, "White Mythology: Metaphor in the Text of Philosophy" [12]. 
Although Mr. Tweedy is convinced that the chickens are "organized," as he puts it [7], Mrs. Tweedy remains incredulous toward both Mr. Tweedy and the chickens.

After Rocky has begun to teach the chickens how to fly with little apparent success, a large truck mysteriously arrives on the farm, unloading heavy machinery and other equipment. Then, during Mrs. Tweedy's next inspection, she spares Babs's life despite the hen's failure to produce any eggs for the week and orders Mr. Tweedy to double the chickens' food rations. Ginger realizes that they are all being fattened for slaughter, and the rest of the chickens despair of ever escaping from the farm. When Rocky tries to cheer them up with a dance party that night, Ginger notices that his wing has healed and asks him to personally demonstrate how to fly the next morning. At the same time, Mr. Tweedy finishes assembling the machinery, and Mrs. Tweedy explains to him that instead of producing eggs, their farm would produce chicken pies from now on, using a fully automated production method. Mr. Tweedy captures Ginger in order to test the new machine out, but Rocky rescues her and sabotages the machine in the process. The next morning, Ginger finds that Rocky has gone and left the remaining piece of the torn poster behind, revealing that he is shot out of a cannon for his "flying" act at the circus. As the rest of the chickens turn on each other in frustration, Ginger devises a new plan to escape from the farm by building an airplane, inspired by Fowler's constant anecdotes about his RAF service. The chickens begin to build the airplane with the help of the scavenging rats Nick and Fetcher, but when Mr. Tweedy manages to repair the machine, Mrs. Tweedy orders him to load all the chickens into it at once. The chickens attempt to launch their unfinished airplane immediately, and Rocky returns just in time to help them escape from both Mr. and Mrs. Tweedy, destroying the machine and most of the farm itself. The chickens fly away from the farm in their bird-like aircraft, while Ginger and Rocky finally kiss. The film concludes as Ginger, Rocky, and the rest of the chickens start their new life together in a grassy paradise, accompanied by Nick and Fetcher and surrounded by many young chicks as well.

Although Chicken Run certainly lends itself to an allegorical reading in which the chickens' series of attempts to escape from Tweedy's Farm represents the Allied prisoners-of-war's attempts to escape from their Nazi-run prison camps during World War II, I want to argue that Chicken Run cannot be reduced to this allegorical reading. In other words, although there are some elements within the film that do seem to serve the function of humanimallegory, there are also many elements within it that serve other quite different functions. Aardman's animated characters, both human and animal—and Park's characters in particular, like Wallace and Gromit-are well known for their expressiveness or, more specifically, for their very human facial expressions. While this anthropomorphic representation of nonhuman animals might be taken as evidence of the animal's purely symbolic function in Chicken Run, I would rather suggest that this highly stylized animation technique undermines the humanist assumption that the capacity for thought, emotion, or "face" itself 6 is possessed by human beings alone. What I am suggesting is that anthropomorphism does not invariably function in the service of humanism. Some forms of anthropomorphism may even threaten the humanist order of representation. The question of whether the representation of nonhuman animals in Chicken Run is anthropomorphic or not, then, becomes much more interesting once we begin to ask what sort of effects-artistic, political, or otherwise-such an anthropomorphic representation of nonhuman animals produces. ${ }^{7}$ Furthermore, while Chicken Run is largely based on World War II prisoner-of-war films, many of which were based on true stories themselves, it remains a comical parody or spoof whose own story does not neatly

6 On Levinas's concept of the face in relation to the question of the animal, see Tamra Wright, Peter Hughes, and Alison Ainley, "The Paradox of Morality: An Interview with Emmanuel Levinas" [13].

7 For a critical intervention into the scholarly debate on anthropomorphism within the field of animal studies, see Lorraine Daston and Gregg Mitman, eds. Thinking with Animals: New Perspectives on Anthropomorphism [14]. In their introduction to the volume, Daston and Mitman argue that "anthropomorphism sometimes seems dangerously allied to anthropocentrism...[b]ut anthropomorphism and anthropocentrism can just as easily tug in opposite directions" ([14], p. 4). While I might challenge Daston and Mitman's strategic distinction between the "fact" of anthropomorphism and its "value" ([14], p. 6), I remain nonetheless sympathetic to their efforts to "decouple" anthropomorphism from anthropocentrism (see [14], p. 4). 
correspond to real human characters or historical events. Indeed, the film derives much of its humor from its sly sense of intertextuality. In addition to its repeated references to the classic prisoner-of-war film The Great Escape, produced and directed by John Sturges and released in 1963 [15] — the most amusing of which is perhaps the reference to the solitary confinement scene in The Great Escape where the troublesome American prisoner Hilts bounces a baseball against one wall of the small cell to which his Nazi captors have confined him by an early scene in Chicken Run where Ginger similarly bounces a Brussels sprout against one side of the yard bin into which Mr. Tweedy has thrown her-there are many allusions in Chicken Run to other popular visual texts as well, including the Western-comedy film Maverick, the action-adventure film Raiders of the Lost Ark, and the science-fiction television series Star Trek.

Finally, the function of humanimallegory in Chicken Run is greatly diminished if not entirely shut down by the film's attention to species difference, sexual difference, and cultural difference among its various characters, both human and animal. Whereas all the farm animals in Animal Farm speak a common language, allowing them to unite together against Mr. Jones and the rest of the men, Chicken Run focuses on a group of chickens on an egg farm. These chickens are "organized," as Mr. Tweedy puts it, by their own particular language and not by any common language as such that would lump all nonhuman animals together in an undifferentiated mass. Of course, the chickens do speak to the rats Nick and Fetcher in some kind of common language, but this language is formed by their ongoing economic relations with each other on the farm. It is very telling, I think, that neither the chickens nor the rats speak to the guard dogs who help Mr. Tweedy patrol the farm in any sort of common or universal language for nonhuman animals. And whereas all the female characters in Orwell's novel, whether they are human or animal, are sidelined or simply cut from the film Animal Farm, the very plot of Chicken Run hinges on sexual difference while overturning some of the most common gender stereotypes in popular film. The story concerns the contemporary practice of hen farming, to be precise, and the main conflict arises when the farm makes a shift from its traditional method of egg production to a more modern method of meat production, transforming the "layer" hens into "broiler" hens all at once. Moreover, the central protagonist of the story is the courageous and resourceful hen Ginger, who is acknowledged by all the chickens on the farm as their leader, while the principal antagonist is the domineering farmer's wife Mrs. Tweedy, who dictates the operation and direction of the farm to her "hen-pecked" husband Mr. Tweedy. Although the film does run the risk of reinforcing certain gender stereotypes in order to challenge more dominant ones, its critical attention to sexual difference among both its human and animal characters is far more interesting than Animal Farm's utter neglect of it. And again, whereas cultural difference plays a negligible part in Animal Farm, Chicken Run is populated by characters with very diverse and distinctive English accents denoting important social and political divisions, an element of the film that is not likely to be lost on any British audience at least. This is not to mention the American rooster Rocky, to whom the older English rooster Fowler takes an immediate dislike, and the Scottish hen Mac, whose strong vernacular Rocky can hardly understand himself in a running joke throughout the film. While both Rocky and Mac serve as references to some of the main characters among the Allied prisoners-of-war in The Great Escape, they also provide the occasion for further intertextual references to Maverick and Star Trek, respectively.

What I am arguing, then, is that the irreducible heterogeneity of Chicken Run's various human and animal characters-a heterogeneity that is articulated by their species, sexual, and cultural difference-limits or curbs the function of humanimallegory insofar as the animals in the film do not act as mere symbols for human referents. Although an allegorical reading of Chicken Run is possible, it cannot dominate or exhaust all its other possible readings-not because the film remains disengaged from the practice of representation altogether, but rather because it is engaged in a multiform set of representational practices that cannot be reduced to the single function of allegory. Exceeding the strict economy of the humanimallegory, the animal is thus neither a pure symbol nor a transcendental referent. It should be needless to say that this also goes for the human. Chicken Run may tell the story of an ambitious escape attempt made by Allied prisoners-of-war during World War II, but this does 
not prevent it from telling another story as well-a story about another ambitious escape attempt, whether real or fictional, made by a group of chickens on an egg farm.

Yet we must not jump to the conclusion that Chicken Run is "really" a story about an animal revolution, either. Although Aardman's film cannot be exhausted by any allegorical reading, the humanist compulsion to read it as an allegory persists nonetheless-a compulsion that is clearly displayed by one of the film's most authoritative sources, Peter Lord, the cofounder of Aardman and the co-director and co-producer of Chicken Run himself. In the short documentary feature "Poultry in Motion: The Making of Chicken Run," after both the actor Mel Gibson who voices Rocky in the film ${ }^{8}$ and one of the film's executive producers Jeffrey Katzenberg have explained that Chicken Run is based on World War II prisoner-of-war films like The Great Escape, Lord comments on the film: "The thing about chickens is of course they're such stupid animals, so immediately there's this incredibly rich vein of absurdity [running] through it" [16]. Even Lord, then, favors an allegorical reading of Chicken Run in which the animated chickens only act as symbols for human prisoners-of-war. It seems that while the function of humanimallegory is only one function among others, it is marked by a particularly authoritarian bent, striving to assimilate all other functions into itself. But Lord is not the sole "author" of Chicken Run, and I like to think that Nick Park, the creator of Wallace and Gromit and Lord's co-director and co-producer, would never have claimed that the film draws its humor from the "stupidity" of real chickens. However, even if Park were to agree with Lord, it would remain all the same that our reading of Chicken Run is not determined once and for all by the author's or coauthors' "intent."

It thus follows that we can read Animal Farm as a story about an animal revolution, after all. For despite John Halas and Joy Batchelor's intent, despite Louis de Rochemont and the CIA's intent, and even despite the author George Orwell's intent, not only does Animal Farm tell the story of the Russian Revolution and the subsequent rise of Stalinism in the Soviet Union, but it also tells another story about a revolution led by a group of farm animals and its aftermath. Although the CIA certainly intended the film Animal Farm to serve as a cultural piece of anti-Soviet propaganda, I would say that this intention was thwarted by de Rochemont's insistence that Halas and Batchelor change the ending of Orwell's story. The film ultimately redeems the Russian Revolution itself, let me point out, by concluding with the farm animals' last revolution against Napoleon and the rest of the pigs-a revolution that, far from destroying the legacy of Old Major and Snowball, preserves and completes it. Ironically, this final redemption of the Russian Revolution in the film Animal Farm is absent in Orwell's own novel.

Yet Orwell's intent does not necessarily determine our reading of the novel, either. Of course, Orwell did intend Animal Farm to be read as an allegory, calling it a "fairy story" himself in the subtitle of his original text. And Orwell's novel has indeed been read as a rather simple animal-human allegory ever since its initial publication. In the review of Halas and Batchelor's film in Time magazine where the word "animallegory" was first coined, it is Orwell's novel itself that is described by this neologism:

8 Gibson voiced the character of Rocky in Chicken Run some years before he would direct, co-produce, and co-write the controversial film The Passion of the Christ, further going on to make some widely publicized anti-Semitic and racist comments that have greatly damaged his professional career. In any case, it is undeniable that our present viewing of Chicken Run is inflected by its close association with the film Maverick in which Gibson plays the title role, Bret Maverick, as much as it is-for better or worse-by its association with the actor Gibson himself.

9 Neither is our reading of Chicken Run determined by the viewing audience or by the visual form of animation itself. For although it might be tempting to suggest that adult viewers are more inclined than younger viewers toward a reductive allegorical reading of this film or that animated films in general are more amenable than live-action films to the allegorical representation of human beings by nonhuman animals, I would resist any such categorical assumptions. The point that live-action films are amenable to the most reductive forms of allegorical representation as well is proven by the crassly ideological and nearly unwatchable made-for-television film Animal Farm, another adaption of Orwell's novel featuring both live and "animatronic" animals, directed by John Stephenson and released in 1999 [17]. 
"George Orwell's political fable, the famous animallegory about Communism, has been rendered as an animated cartoon..." ([5], p. 74). Not only are both Orwell's novels Animal Farm and 1984 widely cited and discussed throughout the existing body of scholarship on allegory, but in Angus Fletcher's work Allegory: The Theory of a Symbolic Mode, he even proposes that there is a peculiarly "Orwellian" structure to allegory as such. Immediately following the passage from his introduction to the text which I have already cited in this paper, Fletcher extends his definition of allegory by referring specifically to 1984:

Pushed to an extreme, this ironic usage [of language by allegory] would subvert language itself, turning everything into an Orwellian newspeak. In this sense we see how allegory is properly considered a mode: it is a fundamental process of encoding our speech. For the very reason that it is a radical linguistic procedure, it can appear in all sorts of different works, many of which fall far short of the confusing doubleness that made Orwell's newspeak such an effective brainwashing device. ([11], pp. 2-3).

But again, if we were to question the humanist presuppositions that are entailed by this definition, then we could say that Orwell's species allegory in Animal Farm is not protected against this subversive force or "doubleness" of language any more than his political allegory in 1984 is protected against it. Although Orwell certainly intended Animal Farm to expose Stalin's betrayal of the Russian Revolution, can we not also read his novel as a political exposé of humanism itself? Does Orwell's novel not also indict the benevolent tyranny of a humanism that continues to thrive in a post-Darwinian world by conceding that humans are animals, all the while maintaining that they are not? Does the last remaining Commandment, which has been corrupted from its original form given in the Seven Commandments of Animalism, not define the governing logic of this post-Darwinian humanism: "All animals are equal but some animals are more equal than others" ([18], p. 134, cf. pp. 23-25)? While the function of humanimallegory thus aims to reduce all animal symbols to their human referents, it only does so by breaching the very distinction that it sets out to maintain between the human and the animal, between the referent and the symbol, between the real and the fictional. Far from calling for some sort of return to a literal reading of the text, then, what I am suggesting is an allegorical reading of the function of humanimallegory in Animal Farm itself-an allegory of allegory, a hyper-allegorical reading of the text in which Orwell's allegory for the Russian Revolution may be read in turn as an allegory for the Animal Revolution. Is this kind of dysfunctional or malfunctional reading not finally "authorized," so to speak, by the function of humanimallegory itself?

Conflicts of Interest: The author declares no conflict of interest.

\section{References}

1. You Never Can Tell. Directed by Lou Breslow. Universal City: Universal Studios Home Entertainment, 2013. DVD.

2. The Island of Dr. Moreau. Directed by Don Taylor. Beverly Hills: MGM Home Entertainment, 2001. DVD.

3. Wells, H. G. The Island of Doctor Moreau. New York: Penguin Books, 2005.

4. Island of Lost Souls. Directed by Erle C. Kenton. New York: Criterion Collection, 2011. DVD.

5. “Cinema." Time 65 (1955): 74-76.

6. Animal Farm. Directed by John Halas and Joy Batchelor. San Francisco: Home Vision Entertainment, 2004, DVD.

7. Chicken Run. Directed by Peter Lord and Nick Park. Universal City: DreamWorks Home Entertainment, 2000. DVD.

8. Lippit, Akira Mizuta. Electric Animal: Toward a Rhetoric of Wildlife. Minneapolis: University of Minnesota Press, 2000.

9. Burt, Jonathan. Animals in Film. London: Reaktion Books, 2002.

10. Wells, Paul. The Animated Bestiary: Animals, Cartoons, and Culture. New Brunswick: Rutgers University Press, 2009.

11. Fletcher, Angus. Allegory: The Theory of a Symbolic Mode, rev. ed. Princeton: Princeton University Press, 2012. 
12. Derrida, Jacques. "White Mythology: Metaphor in the Text of Philosophy." In Margins of Philosophy. Translated by Alan Bass. Chicago: University of Chicago Press, 1982, pp. 207-71.

13. Wright, Tamra, Peter Hughes, and Alison Ainley. "The Paradox of Morality: An Interview with Emmanuel Levinas." In The Provocation of Levinas: Rethinking the Other. Translated by Andrew Benjamin and Tamra Wright. Edited by Robert Bernasconi and David Wood. New York: Routledge, 1988, pp. 168-80.

14. Daston, Lorraine, and Gregg Mitman, eds. Thinking with Animals: New Perspectives on Anthropocentrism. New York: Columbia University Press, 2005.

15. The Great Escape. Directed by John Sturges. Beverly Hills: MGM Home Entertainment, 2004. DVD.

16. “Poultry in Motion: The Making of Chicken Run." In Chicken Run. Directed by Ed W. Marsh. Universal City: DreamWorks Home Entertainment, 2000. DVD.

17. Animal Farm. Directed by John Stephenson. Santa Monica: Lionsgate, 2000. DVD.

18. Orwell, George. Animal Farm: A Fairy Story. New York: Signet Classics, 1996.

(C) 2017 by the author; licensee MDPI, Basel, Switzerland. This article is an open access article distributed under the terms and conditions of the Creative Commons Attribution (CC BY) license (http://creativecommons.org/licenses/by/4.0/). 